\title{
Chemical composition and antioxidant activity of Thymus fontanesii essential oil from Algeria
}

\author{
Lamia Sidali $^{a^{*}}$, Moussa Brada ${ }^{a}$, Marie-Laure Fauconnier $^{b}$, Georges Lognay $^{c}$ \\ ${ }^{a}$ Valuation of Natural Substances Laboratory, Djilali Bounaama University of Khemis-Miliana, Road of \\ Theniet El-Had, 44225, Algeria \\ ${ }^{b}$ Agro-Bio Chem Department, Laboratory of General and Organic Chemistry, University of Liège, Gem- \\ bloux Agro-Bio Tech, 2, Passage of Deportees, B-5030 Gembloux, Belgium \\ ${ }^{c}$ Agro-Bio Chem Department, Laboratory of Analytical Chemistry, University of Liège, Gembloux Agro- \\ Bio Tech, 2, Passage of Deportees, B-5030 Gembloux, Belgium
}

\begin{abstract}
Background: Thymus fontanesii is one of the importance Algerian plant, used traditionally to treat the cough and cold. In addition, it may help to protect the people against lipid peroxidation and oxidative stress and can be used as an antioxidant agent for the preservation of processed food.
\end{abstract}

Objective: The aim of this study was to determine the chemical composition of Algerian Thymus fontanesii essential oil and to test its antioxidant activity.

Method: The oil was extracted by electromagnetic induction (EMI) heating assisted extraction and by hydrodistillation, and was analysed by gas chromatography with flame ionization detector (GC/FID) and gas chromatography/mass spectrometry (GC/MS). The antioxidant activity was evaluated by three assays mainly: DPPH assay, reducing power and $\beta$-carotene/linoleic acid.

Results: The yield of the essential oil was varied from $2.1 \pm 0.3$ to $3.1 \pm 0.1 \%$ (w/w), and from $1.8 \pm 0.01$ to $2.6 \pm$ $0.02 \%(\mathrm{w} / \mathrm{w})$, for the electromagnetic induction heating assisted extraction and hydrodistillation, respectively. Twenty seven components were identified representing $95.6-99.9 \%$ of the oil. Carvacrol (54.7 $\pm 1.2-63.9 \pm 1.9 \%)$ was the major compound followed by $p$-cymene $(9.2 \pm 1.2-17.5 \pm 1.2 \%)$ and $\gamma$-terpinene $(8.8 \pm 0.9-14.9 \pm 0.8 \%)$. The Thymus fontanesii essential oil was found as a significant antioxidant with $\mathrm{IC}_{50}$ values were ranging from $57.3 \pm 1.4$ to $236.7 \pm 1.4 \mu \mathrm{g} / \mathrm{mL}$, which were higher than that of butylated hydroxyl toluene (BHT) choosing as reference $(9.1 \pm 1.2$ to $67.8 \pm 0.1 \mu \mathrm{g} / \mathrm{mL})$.

Conclusion: The obtained results encourage the use of Thymus species with bioactive compounds for further food applications.

\section{Keywords}

Thymus fontanesii, electromagnetic induction heating, hydrodistillation, essential oil, chemical composition, antioxidant activity.

\section{Introduction}

Lamiaceae among which Thymus species are very common in the Mediterranean regions especially in dry and arid environments. The diversity of their essential oils biological properties may be a consequence of their rich chemical diversity, and in part explains the large number of studies investigating their chemical composition [1-2]. Thymus genus is divided in eight 
sections, comprising 215 species and eleven of them are in the flora of Algeria [3]. Thymus fontanesii Boiss. \& Reut, a spontaneous aromatic plant, endemic to Algeria and Tunisia [4] is used in Algerian traditional medicine, as antispasmodic, carminative, stomachic, expectorant, antitussive, antiseptic and anthelminitic remedy in some gastrointestinal diseases [5], and widely used to treat respiratory infections, irritation of throat and respiratory organs [6].

Some reports on the chemical composition of Thymus fontanesii essential oil (TFEO) revealed that carvacrol and thymol represent the most important compounds in the species flowed by $p$-cymene and $\gamma$ terpinene [5-9]. Concerning the biological properties of T. fontanesii essential oil, there are some studies on the antimicrobial activity [7-9], antidermatophytic activity $[10]$ and anti-inflammatory activity $[6,8]$, but there are not studies on their antioxidant activity.

The present study has therefore been designed to characterize the essential oil of Thymus fontanesii from North Algeria obtained by two different extraction techniques and evaluate its antioxidant activity.

\section{Materials and Methods}

\subsection{Plant material and isolation procedure}

The aerial parts of $T$. fontanesii were collected during the flowering period from three different regions Miliana (M, latitude: $\mathrm{N} 36^{\circ} 17^{\prime}$; longitude: W2 ${ }^{\circ} 3^{\prime}$; altitude: $723 \mathrm{~m}$ ), Tarik Ibn Ziad (TIZ, latitude: N36 00 '; longitude: W2 09 '; altitude: $630 \mathrm{~m}$ ) and Oued El Chorfa (OEC, latitude: $36^{\circ} 12^{\prime} 00^{\prime \prime}$; longitude: W2 31'00'; altitude: $460 \mathrm{~m}$ ) located in Northern Algeria. Voucher specimens were deposited in the herbarium of the Agronomic Department of Khemis Miliana University (references: $\mathrm{T}_{\mathrm{M}}, \mathrm{T}_{\mathrm{TIZ}}$ and $\mathrm{T}_{\mathrm{OEC}}$, respectively).

The essential oil was extracted from each of the samples by two extraction methods, in order to introduce the electromagnetic induction (EMI) heating assisted extraction as a new technique of extraction. Therefore, the yield and chemical composition of
TFEO extracted by EMI heating were studied and compared with those obtained by hydrodistillation.

- Hydrodistillation (HD): Fifty five grams of aerial parts of $T$. fontanesii (cut into small pieces of 0.5 to $1 \mathrm{~cm}$ and dried at room temperature $\sim 20{ }^{\circ} \mathrm{C}$ for 10 days) were submitted to hydrodistillation with a Clevenger apparatus, and extracted for $2 \mathrm{~h}$ The essential oil was collected by decantation and stored in closed dark vials at $4^{\circ} \mathrm{C}$ until analysis.

Electromagnetic induction heating assisted extraction (EMI): The aerial parts of collected plants were subjected an EMI heating assisted extraction. The system was equipped with a pressure cooker (5 L capacity), placed on an induction plate $(1800 \mathrm{~W})$, whereas the extraction was carried out in magnetizable conditions. The essential oil was collected by decantation and dried over anhydrous sodium sulfate, the yield measured, and stored in a freezer at $4^{\circ} \mathrm{C}$ in dark glass bottles until use.

The following formula was used to determine the essential oils yield:

Essential oil yield $(\%)=\left(\mathrm{W}_{1} / \mathrm{W}_{2}\right) \times 100$

Where W1 is the net weight of TFEO $(\mathrm{g})$ and $\mathrm{W} 2$ is the total weight of dried aerial parts of $T$. fontanesii $(\mathrm{g})$

\subsection{Essential oil analyses}

$5 \mathrm{mg}$ of oil was dissolved in $2.5 \mathrm{~mL}$ pure diethyl ether and further analyzed by gas chromatography/flame ionization detector (GC-FID) and gas chromatography/mass spectrometry (GC-MS).

GC-FID: The analysis of the extracted oil was carried out by means of a HP 6890A gas chromatograph fitted with FID. Using a capillary column coated with $5 \%$ phenyl-methylsiloxane $(30 \mathrm{~m}$ x $0.25 \mathrm{~mm}$ x $0.25 \mu \mathrm{m}$ film thickness, Agilent Technologies, Hewlett-Packard, CA, USA); column temperature program was the following: from $40{ }^{\circ} \mathrm{C}(1 \mathrm{~min})$ to $200{ }^{\circ} \mathrm{C}$ at $6{ }^{\circ} \mathrm{C} / \mathrm{min}$, $200-280{ }^{\circ} \mathrm{C}$ at $30{ }^{\circ} \mathrm{C} / \mathrm{min}, 280{ }^{\circ} \mathrm{C}$ (final hold of 2 min). The injections have been performed in splitess mode and injector temperature was set at $280{ }^{\circ} \mathrm{C}$; 
detector temperature $300{ }^{\circ} \mathrm{C}$; volume injected was $1 \mu \mathrm{L}$ of diluted oil in diethyl ether. The carrier gas was helium at flow rate of $1 \mathrm{~mL} / \mathrm{min}$.

GC-MS: GC-MS was carried out using an Agilent 5973 GC-MS coupled to an Agilent 6890 gas chromatograph fitted with a split-splitless injector at $250{ }^{\circ} \mathrm{C}$ (splitless mode). The analytical conditions have been fixed as follows: Agilent HP-5MS capillary column (30 m x $0.25 \mathrm{~mm}$, df $=0.25 \mu \mathrm{m})$, temperature program: from $40-250{ }^{\circ} \mathrm{C}$ at $6{ }^{\circ} \mathrm{C} / \mathrm{min}$. The carrier gas was helium at flow rate of $1 \mathrm{~mL} / \mathrm{min}$. The mass spectra have been recorded in EI mode at $70 \mathrm{eV}$ (scanned mass range: 35 to $500 \mathrm{amu}$ ). The source and quadrupole temperatures were fixed at $230{ }^{\circ} \mathrm{C}$ and $150{ }^{\circ} \mathrm{C}$, respectively. The identification of the components was performed on the basis of chromatographic retention indices (RI) and by comparison of the recorded spectra with a computed data library (Wiley 275.L). For sesquiterpene hydrocarbons, further confirmations were obtained by comparing the mass spectra with data from the literature $[11,12]$. RI values were measured on an HP-5MS column. RI calculations were performed in temperature programmation mode according to [13], a mixture of homologues $n$-alkanes $\left(\mathrm{C}_{7}-\mathrm{C}_{30}\right)$ was used, under the same chromatographic conditions. Main components have been confirmed by comparison of their retention data with co-injected pure (commercially available) references.

\subsection{Antioxidant activity}

\subsubsection{DPPHassay}

The stable 2,2-diphenyl-1-picrylhydrazyl radical (DPPH') was used for determination of free radical scavenging activity of the essential oils [14]. Fifty microliters of various concentrations of the samples $(25,50,75$ and $100 \mu \mathrm{g} / \mathrm{mL}$ ) in methanol (essential oil and BHT) were added to $2 \mathrm{~mL}$ of $60 \mu \mathrm{M}$ methanol solution of DPPH: After $20 \mathrm{~min}$ at room temperature, the absorbance was recorded at $517 \mathrm{~nm}$, absorption of the blank sample containing the same amount of methanol and DPPH solution acted as the negative control. Butylated hydroxyl toluene (BHT) at $(25,50$, 75 and $100 \mu \mathrm{g} / \mathrm{mL}$ ) was used as positive control The percentage inhibition of the DPPH radical by the samples was calculated according to the formula:

$$
\% \text { Inhibition }=\left[\left(\mathbf{A}_{b}-\mathbf{A}_{a}\right) / \mathbf{A}_{b}\right] \times 100
$$

where $A_{b}$ is the absorbance of the blank sample and $A_{a}$ is the absorbance of the test sample.

The sample concentration providing inhibition $\left(\mathrm{IC}_{50}\right)$ was calculated by plotting the inhibition percentages against the concentration of sample.

\subsubsection{Reducing power determination}

The reducing power of the essential oil and standards was determined according to the protocol of Hseu et al. [15]. In brief, $1 \mathrm{~mL}$ of different concentrations of the samples $(25,50,75$ and $100 \mu \mathrm{g} / \mathrm{mL})$ was mixed with phosphate buffer $(1 \mathrm{~mL}, 0.2 \mathrm{M}, \mathrm{pH}=6.6)$ and $1 \%$ potassium ferricyanide $\left[\mathrm{K}_{3} \mathrm{Fe}(\mathrm{CN})_{6}\right]$ solution $(1 \mathrm{~mL})$. The mixture was incubated at $50{ }^{\circ} \mathrm{C}$ for $20 \mathrm{~min}$. Trichloroacetic acid (TCA) (1 mL, 10\%) was added to the solution, which was then centrifuged for $10 \mathrm{~min}$ at $3000 \mathrm{~g}$. The supernatant was recovered and mixed with distilled water $(1.5 \mathrm{~mL})$ and $0.1 \% \mathrm{FeCl}_{3}(150 \mu \mathrm{L})$ and the absorbance was measured at $700 \mathrm{~nm}$. Absorbance increase of the reaction mixture (according to the blank) indicated increased reducing power.

\subsection{3. $\quad \beta$-carotene/linoleic acid bleaching assay}

The $\beta$-carotene/linoleic acid test evaluated the inhibitory effect of a compound or a mixture on the oxidation of $\beta$-carotene in the presence of molecular oxygen $\left(\mathrm{O}_{2}\right)$. Assay of $\beta$-carotene gives an estimation of the antioxidant potential of the sample. The method described by Miraliakbari and Shahidi [16] was used; a mixture of $\beta$-carotene and linoleic acid was prepared by adding together $0.5 \mathrm{mg}$ of $\beta$-carotene in $1 \mathrm{~mL}$ of chloroform, $25 \mu \mathrm{L}$ pure linoleic acid and $200 \mathrm{mg}$ Tween 40. The chloroform was then completely evaporated under vacuum and $100 \mathrm{~mL}$ of oxygenated water was subsequently added to the residue and mixed 
to form a clear yellowish emulsion. Three hundred and fifty microliters of various concentrations of sample $(25,50,75$ and $100 \mu \mathrm{g} / \mathrm{mL}$ ) in methanol (essential oil and BHT) were added to $2.5 \mathrm{~mL}$ of the above emulsion in test tubes and mixed. The test tubes were incubated in water bath at $50^{\circ} \mathrm{C}$ for $2 \mathrm{~h}$ together with a negative control (blank) containing pure methanol instead of sample.

The absorbance values were measured at $470 \mathrm{~nm}$. Antioxidant activity (percentage inhibition, \% I) of the samples was calculated as follows:

\section{$\% \mathrm{I}=[\mathrm{A}(\boldsymbol{\beta}$-carotene after $2 \mathrm{~h}$ assay)/A (initial $\beta$-carotene)] x 100

where $A$ ( $\beta$-carotene after $2 \mathrm{~h}$ assay) is the absorbance value of $\beta$-carotene after $2 \mathrm{~h}$ assay remaining in the samples whereas A (initial $\beta$-carotene) is the absorbance value of $\beta$-carotene from the standard freshly prepared solution. The activity was calculated as $50 \%$ inhibition concentration $\left(\mathrm{IC}_{50}\right)$.

All experiments were repeated three times on independent samples and the data were expressed as mean \pm standard deviation $(\mathrm{SD})$.

\section{Results and Discussion}

\subsection{Essential oil yield and chemical composition}

T. fontanesii samples gave yellow liquid with sharp odor and yield ranging from $2.1 \pm 0.3 \%$ to $3.1 \pm 0.1 \%$, (w/w) for EMI heating and $1.8 \pm 0.01 \%$ to $2.6 \pm 0.02 \%$, (w/w) for HD. Figure 1 showed the variation of the extraction yield of TFEO from Tarik Ibn Ziad according to the extraction time. Three phases were observed in the process of the EMI heating. The first phase $(0-10 \mathrm{~min})$ represented the preheating time from room temperature to $140{ }^{\circ} \mathrm{C}$. The second phase (10 - $55 \mathrm{~min})$ was presented by increasing yields, representing $2.9 \%$ of oil relative to the initial amount of TFEO. The third phase corresponds to a plateau, which marked the end of extraction process. Therefore, the max yiled was $2.9 \%$ after 55 min of extraction.
HD lead to a max of $2.1 \%$ essential oil yield and the end of extraction process was reached after $85 \mathrm{~min}$. The higher yield was found for the samples from Miliana (from $2.6 \pm 0.02 \%$ to $3.1 \pm 0.1 \%$ ), while the lower yield was found for the samples from Oued El Chorfa (from $1.8 \pm 0.01 \%$ to $2.1 \pm 0.3 \%$ ), and for $T$. fontanesii from Tarik Ibn Ziad (from $2.1 \pm 0.01 \%$ to $2.9 \pm 0.1 \%$ ). These results were in line with those obtained by Haddouchi, Lazouni and Meziane [17] (2\%) and Ghannadi, Sajjadi and Kabouche [5] (1.9\%), but they were higher than those obtained by Dob et al. [9] $(0.9 \%)$. The EMI heating assisted extraction showed better results, which can be considered quite an innovate isolation and efficiency technique comparative by the Clevenger apparatus, this efficiency was probably based on the interaction between the speed of the EMI heating and evaporation of the essential oil from vegetable material.

Fig 1. Variation of T. fontanesii essential oils yields from Tarik Ibn Ziad according to extraction time.

The results of TFEO characterization are gathered in Table 1. Twenty six and twenty four compounds were identified in TFEO from TIZ extracted by the EMI and HD, represented $99.8 \%$ and $95.6 \%$ of EO (Table 1). Higher amounts of oxygenated monoterpenes were presented in the TFEO isolated by EMI heating (67.6\%) compared to HD (59.6\%). Whereas, the monoterpene hydrocarbons were presented in high proportions in HD (35.71\%) compared to EMI heating $(31 \%)$ essential oil, which there were less valuable than oxygenated compounds in terms of their contribution to fragrance of the essential oil. Conversely, the oxygenated compounds are highly odoriferous. Carvacrol is the main component in the TFEO but the relative amounts differed for the two isolation methods: $63.9 .8 \pm 1.9 \%$ for EMI heating and $54.7 \pm 1.2 \%$ for $\mathrm{HD}$, respectively. $p$-Cymene and $\gamma$ terpinene were the two other main components in TFEO. The highest proportion of $p$-cymene was found in HD essential oil $(17.5 \pm 1.2 \%)$ compared with EMI heating essential oil $(10.5 \pm 0.2 \%)$ and $\gamma$-terpinene is more abundant in EMI heating (14.9 $\pm 0.8 \%)$ against 
$8.8 \pm 0.9 \%$ in HD. Therefore, the EMI heating, highly accelerated the extraction process, without major difference in proportions of compounds.

Twenty seven compounds representing 99.9, 99.8 and $96.9 \%$ of M, TIZ and OEC oils, respectively. Oxygenated monoterpenes was the predominant chemical group $(62.1-67.6 \%)$, followed by the monoterpenes (31-35.1\%), whereas the sesquiterpenes $(0.9-1.2 \%)$ and oxygenated sesquiterpenes (0.1 $0.2 \%$ ) proportions were very low. The major components were carvacrol $(55.1 \pm 0.8-63.9 \pm 1.9 \%)$, a phenolic molecule with significant antioxidant activity [18-20], $p$-cymene $(9.2 \pm 1.2-14.3 \pm 1.3 \%)$ and $\gamma$-terpinene $(11.6 \pm 1.5-14.9 \pm 0.8 \%)$.

These results are in agreement with those of Bekhechi et al. [7] and indicate that Thymus fontanesii of the present study belongs to a "carvacrol chemotype" [6]. In other essential oils of T. fontanesii from Algeria $[5,9]$, the major components were thymol $(67.8 \%), p$ cymene $(13 \%)$ and $\gamma$-terpinene $(15.9 \%)$ with a low content of carvacrol (1.7\%).

This large variability in the chemical composition of different species of Algerian TFEO samples could be due that several factors including abiotic (local climate and environment like temperature, sun, location and nutriments) [21], biotic factors as intraspecific chemotypes [22] and harvesting (phenological stage) season. In fact, the comparison of the oil composition obtained from the three $T$. fontanesii samples showed some quantitative differences. Other previous study of some Thymus species confirmed that the environmental conditions play an important role in the chemical variations $[22,23]$.

Table 1. Chemical composition of the essential oil of $T$. fontanesii from Algeria (mean of triplicates)

\subsection{Antioxidant activity of T. fontanesii essential oil}

The antioxidant activity of TFEO was assessed by three antioxidant assays: the $\mathrm{DPPH}$ assay, evaluating the H-donating or radical scavenging ability of the oil using the stable radical 2,2-diphenyl-1-picrylhydrazyl as a reagent, an assay estimating the ferric-reducing capacity of the oil and the $\beta$-carotene/linoleic acid bleaching assay. The concentration that led to $50 \%$ inhibition or effectiveness $\left(\mathrm{IC}_{50}\right)$ values reflected better protective actions. As shown in Table 2, the classification order of antioxidant power was the same for all assays, with in decreasing order, TIZ sample, followed by $M$ and OEC. The TFEO sample of TIZ showed the higher capacity for scavenging free radicals $\left(\mathrm{IC}_{50}=57.3 \pm 1.4 \mu \mathrm{g} / \mathrm{mL}\right)$, while $\mathrm{TM}$ and TOC $\left(\mathrm{IC}_{50}=\right.$ $83.8 \pm 0.5 \mu \mathrm{g} / \mathrm{mL}$ and $\mathrm{IC}_{50}=91.2 \pm 1.1 \mu \mathrm{g} / \mathrm{mL}$, respectively), but all three samples were less effective than the reference antioxidant butylated hydroxyl toluene $(\mathrm{BHT})(18.3 \pm 0.8 \mu \mathrm{g} / \mathrm{mL})$. Some reports have carried out evaluations of antioxidant activity based on the DPPH in different Thymus species such as $T$. pallescence from Algeria, T. capitatus from Tunisia, $T$. saturejoides from Morocco rich in carvacrol [24-26] and other Thymus species from Lybia rich in thymol [27]. In most such studies, phenolic compounds, due to their chemical structures that allow then to donate hydrogen to free radicals, were introduced as the major factor contributing to the antioxidant activity of EO [28]. The antioxidant activity of TFEO was also assessed by the reducing power assay and the results are gathered in Table 2. For the measurements of the EOs reductive abilities, the transformation of $\mathrm{Fe}^{3+}$ $\mathrm{Fe}^{2+}$ in the presence of oil were investigated. Where, the greatest effectiveness was shown by TIZ sample $(63.8 \pm 0.17 \mu \mathrm{g} / \mathrm{mL})$, slightly lower for $\mathrm{M}$ sample $(103.9 \pm 0.4 \mu \mathrm{g} / \mathrm{mL})$, and the lowest for OEC sample $(112.6 \pm 1.8 \mu \mathrm{g} / \mathrm{mL})$, compared to positive control, BHT $(9.7 \pm 1.23 \mu \mathrm{g} / \mathrm{mL})$. These results showed that the reducing power of TFEO was in line with Thymus marocanus Ball essential oil from Morocco (61.4 \pm $1.58 \mu \mathrm{g} / \mathrm{mL}$ ) rich in carvacrol [14]. Previous studies had indicated that the high reducing power of the Thymus EO was not directly related to its carvacrol and thymol contents, but the substitution of hydroxyl group in the aromatic ring might have contributed to its antioxidant activity [29]. TFEO and BHT prevented the 
bleaching of $\beta$-carotene, whereas TIZ oil $\left(\mathrm{IC}_{50}=148.9\right.$ $\pm 0.45 \mu \mathrm{g} / \mathrm{mL})$ was better than that of $\mathrm{M}(167.2 \pm 0.9$ $\mu \mathrm{g} / \mathrm{mL})$ and OEC $(236.7 \pm 1.4 \mu \mathrm{g} / \mathrm{mL})$ oils. These results were less potent than the references BHT $(67.8$ $\pm 0.1 \mu \mathrm{g} / \mathrm{mL}$ ) and almost similar to $T$. saturejoides essential oil $(213.61 \pm 1.74 \mu \mathrm{g} / \mathrm{mL})$ from Morocco rich in carvacrol and borneol [25]. $\beta$-carotene bleaching inhibition based on the loss of the yellow color of $\beta$ carotene due to its reaction with radicals produced during linoleic acid auto-oxidation in an emulsion [30]. TFEO of the three collection regions was found to be relatively active in all assays. While it appears that there was a very positive correlation between carvacrol content and high antioxidant potential, also the literature review showed that the presence of carvacrol in essential oil of Thymus species may be the main cause of its high antioxidant activity [31,32]. On the other hand, the data obtained from the evaluation of antioxidant activity of TFEO in this research were comparable to the results reported on some Algerian Thymus [26,33] and other Thymus species [27,28,34,35], which the antioxidant potential was addressed to the phenolic compounds (thymol and carvacrol). Monoterpene hydrocarbons, particulary $\alpha$ terpinene and $\gamma$-terpinene, could be also taken into account for the antioxidant activity [36].

Table 2: $\mathrm{IC}_{50}$ values $(\mu \mathrm{g} / \mathrm{mL})$ of $T$. fontanesii essential oil and BHT

\section{Conclusion}

In this study, the EMI assisted heating was presented as an extraction method suitable for essential oil extraction. It resulted a reduced extraction time. Moreover, alteration of essential oil constituents is surely limited in comparison with classical hydrodistillation process (Clevenger apparatus). After 55 min of EMI assited extraction at $140^{\circ} \mathrm{C}$, it was possible to collect almost all the existing essential oils from the three samples with a yield from $2.1 \pm 0.3$ to $3.1 \pm 0.8 \%(\mathrm{w} / \mathrm{w})$, but the high temperature of electromagnetic induction heating is probably causing the degradation of compounds. Carvacrol was found as a major compound in all TFEOs samples with a higher amount in the oil from Tarik Ibn Ziad, followed by $p$ cymene and $\gamma$-terpinene. The antioxidant activity of TFEO was evaluated and $\mathrm{IC}_{50}$ values were raining from $57.3 \pm 1.4$ to $236.7 \pm 1.4 \mu \mathrm{g} / \mathrm{mL}$. These results revealed the importance of $T$. fontanesii as an antioxidant, which, is may help to protect the people against lipid peroxidation and free radical damage. In addition, the essential oil of $T$. fontanesii can be used as an antioxidant agent for the preservation of processed food and as functional food components.

\section{References}

[1] Stahl-Biskup, E.; Sáez, F. Thyme: the genus Thymus: Medicinal and Aromatic Plants; London, 2002, p 330.

[2] Giuliani, C.; Bini, L. M. Insight into the structure and chemistry of glandular trichomes of Labiatae, with emphasis on subfamily Lamioideae. Plant Syst. Evol, 2008, 276 (3-4), 199.

[3] Morales, R. The history, botany and taxonomy of the genus Thymus., 2002, 1-43.

[4] Quezel, P. S. Nouvelle flore de l'Algérie et des régions désertiques méridionales, 1963, Paris 7 804-806.

[5] Ghannadi, A.; Sajjadi, S. E.; Kabouche, A. Thymus fontanesii Boiss. \& Reut.-A potential source of thymol-rich essential oil in North Africa. Z. Naturforsch. C, 2004, 59 (3-4), 187189.

[6] Mouhi, L.; Moghrani, H.; Nasrallah, N.; Amrane, A.; Maachi, R. Anti- inflammatory activity of essential oil of an endemic Thymus fontanesii Boiss. \& Reut. with chemotype carvacrol, and its healing capacity on gastric lesions. J. Food Biochem., 2017, 1-9.

[7] Bekhechi, C.; Bekkara, F. A.; Abdelouahid, D. E.; Tomi, F.; Casanova, J. Composition and Antibacterial Activity of the Essential Oil of 
Thymus fontanesii Boiss. et Reut. from Algeria.

J. Essent. Oil Res., 2007, 19 (6), 594-596.

[8] Sidali, L.; Brada, M.; Fauconnier, M.-L.; Lognay, G.; Heuskin, S., Chemical composition, acute toxicity, antimicrobial and antiinflammatory activities of Thymus fontanesii essential oil from Algeria. PhytoChem Biosub J., 2017, 11 (1), 11.

[9] Dob, T.; Dahmane, D.; Benabdelkader, T.; Chelghoum, C. Composition and Antimicrobial Activity of the Essential Oil of Thymus fontanesii. Pharm. Biol, 2006, 44 (8), 607-612.

[10] Aouati, K.; Mebarki, N.; Ayadi, A.; Chader, H.; Nabiev, M.; Mansouri, M. Évaluation de l'activité antidermatophytique d'une formulation pâteuse à base de l'huile essentielle de Thymus fontanesii. Annales de Dermatologie et de Vénéréologie, Elsevier Masson: 2011; p A193.

[11] Adams, R. Quadrupole mass spectra of compounds listed in order of their retention time on DB-5. Identification of essential oils components by gas chromatography/quadrupole mass spectroscopy. Quadruple mass spectroscopy. Allured Publishing Corporation; USA, 2001, $3^{\text {rd }}$ ed, 456.

[12] Joulain, D.; König, W. A. J. The Atlas of Spectral Data of Sesquiterpene Hydrocarbons. E.B. - Verlag Hambourg.

[13] Babushok, V.; Linstrom, P.; Zenkevich, I. Retention indices for frequently reported compounds of plant essential oils. J. Phys. Chem. Ref. Data, 2011, 40 (4), 043101.

[14] Jamali, C. A.; Kasrati, A.; Bekkouche, K.; Hassani, L.; Wohlmuth, H.; Leach, D.; Abbad, A. Phenological changes to the chemical composition and biological activity of the essential oil from Moroccan endemic thyme (Thymus maroccanus Ball). Ind Crops Prod., 2013, 49, 366-372.

[15] Hseu, Y.-C.; Chang, W.-H.; Chen, C.-S.; Liao, J.-W.; Huang, C.-J.; Lu, F.-J.; Chia, Y.-C.; Hsu,
H.-K.; Wu, J.-J.; Yang, H.-L. Antioxidant activities of Toona Sinensis leaves extracts using different antioxidant models. Food Chem. Toxicol, 2008, 46 (1), 105-114.

[16] Miraliakbari, H.; Shahidi, F. Antioxidant activity of minor components of tree nut oils. Food Chem, 2008, 111 (2), 421-427.

[17] Haddouchi, F.; Lazouni, H. A.; Meziane, A.; Benmansour, A. Etude physicochimique et microbiologique de l'huile essentielle de Thymus fontanesii Boiss \& Reut. Afrique Science. Revue Internationale des Sciences et Technologie, 2009, 5 (2).

[18] Yanishlieva, N. V.; Marinova, E. M.; Gordon, M. H.; Raneva, V. G. Antioxidant activity and mechanism of action of thymol and carvacrol in two lipid systems. Food Chem, 1999, 64 (1), 5966.

[19] Safaei-Ghomi, J.; Ebrahimabadi, A. H.; DjafariBidgoli, Z.; Batooli, H. GC/MS analysis and in vitro antioxidant activity of essential oil and methanol extracts of Thymus caramanicus Jalas and its main constituent carvacrol. Food Chem, 2009, 115 (4), 1524-1528.

[20] Quiroga, P. R.; Asensio, C. M.; Nepote, V. Antioxidant effects of the monoterpenes carvacrol, thymol and sabinene hydrate on chemical and sensory stability of roasted sunflower seeds. J. Sci. Food Agric., 2015, 95 (3), 471-479.

[21] Viuda-Martos, M.; Abd El-Nasse, G. S.; Gendy, El.; Sendra, E.; Fernández-López, J.; Abd El Razik, K.;. Omer Elsayed A.; A. Pérez-Álvarez, J. Chemical Composition and Antioxidant and Anti-Listeria Activities of Essential Oils Obtained from Some Egyptian Plants. J. Agric. Food Chem. 2010, 58, 9063-9070.

[22] De Lisi, A.; Tedone, L.; Montesano, V.; Sarli, G.; Negro, D. Chemical characterisation of Thymus populations belonging from Southern Italy. Food Chem, 2011, 125 (4), 1284-1286. 
[23] Boira, H.; Blanquer, A. Environmental factors affecting chemical variability of essential oils in Thymus piperella L. Biochem. Syst. Ecol., 1998, 26 (8), 811-822.

[24] Bounatirou, S.; Smiti, S.; Miguel, M. G.; Faleiro, L.; Rejeb, M. N.; Neffati, M.; Costa, M.; Figueiredo, A.; Barroso, J.; Pedro, L. Chemical composition, antioxidant and antibacterial activities of the essential oils isolated from Tunisian Thymus capitatus Hoff. et Link. Food Chem, 2007, 105 (1), 146-155.

[25] Kasrati, A.; Jamali, C. A.; Fadli, M.; Bekkouche, K.; Hassani, L.; Wohlmuth, H.; Leach, D.; Abbad, A. Antioxidative activity and synergistic effect of Thymus saturejoides Coss. essential oils with cefixime against selected food-borne bacteria. Ind Crops Prod., 2014, 61, 338-344.

[26] Hazzit, M.; Baaliouamer, A.; Faleiro, M. L.; Miguel, M. G. Composition of the essential oils of Thymus and Origanum species from Algeria and their antioxidant and antimicrobial activities. J. Agric. Food. Chem., 2006, 54 (17), 6314-6321.

[27] Nikolić, M.; Glamočlija, J.; Ferreira, I. C.; Calhelha, R. C.; Fernandes, Â.; Marković, T.; Marković, D.; Giweli, A.; Soković, M. Chemical composition, antimicrobial, antioxidant and antitumor activity of Thymus serpyllum L., Thymus algeriensis Boiss. and Reut and Thymus vulgaris L. essential oils. Ind Crops Prod., 2014, 52, 183-190.

[28] Tohidi, B.; Rahimmalek, M.; Arzani, A. Essential oil composition, total phenolic, flavonoid contents, and antioxidant activity of Thymus species collected from different regions of Iran. Food Chem, 2017, 220, 153-161.

[29] Jabri-Karoui, I.; Bettaieb, I.; Msaada, K.; Hammami, M.; Marzouk, B. Research on the phenolic compounds and antioxidant activities of Tunisian Thymus capitatus. J Funct Foods., 2012, 4 (3), 661-669.
[30] Hazzit, M.; Baaliouamer, A.; Veríssimo, A.; Faleiro, M.; Miguel, M. G. Chemical composition and biological activities of Algerian Thymus oils. Food Chem, 2009, 116 (3), 714-721.

[31] Sokmen, A.; Gulluce, M.; Akpulat, H. A.; Daferera, D.; Tepe, B.; Polissiou, M.; Sokmen, M.; Sahin, F. The in vitro antimicrobial and antioxidant activities of the essential oils and methanol extracts of endemic Thymus spathulifolius. Food control, 2004, 15 (8), $627-$ 634.

[32] Tepe, B.; Sokmen, M.; Akpulat, H. A.; Daferera, D.; Polissiou, M.; Sokmen, A. Antioxidative activity of the essential oils of Thymus sipyleus subsp. sipyleus var. sipyleus and Thymus sipyleus subsp. sipyleus var. rosulans. J. Food Eng., 2005, 66 (4), 447-454.

[33] Lehbili, M.; Chibani, S.; Kabouche, A.; Semra, Z.; Smati, F.; Abuhamdah, S.; Touzani, R.; Kabauche, Z. Composition, antibacterial and antioxidant activity of the essential oil of Thymus guyonii de Noé from Algeria. Der Pharmacia Lettre, 2013, 5 (2), 306-310.

[34] El Bouzidi, L.; Jamali, C. A.; Bekkouche, K.; Hassani, L.; Wohlmuth, H.; Leach, D.; Abbad, A. Chemical composition, antioxidant and antimicrobial activities of essential oils obtained from wild and cultivated Moroccan Thymus species. Ind Crops Prod., 2013, 43, 450-456.

[35] Ertas, A.; Boga, M.; Yilmaz, M. A.; Yesil, Y.; Tel, G.; Temel, H.; Hasimi, N.; Gazioglu, I.; Ozturk, M.; Ugurlu, P. A detailed study on the chemical and biological profiles of essential oil and methanol extract of Thymus nummularius (Anzer tea): Rosmarinic acid. Ind Crops Prod., 2015, 67, 336-345.

[36] Ruberto, G.; Baratta, M. T. Antioxidant activity of selected essential oil components in two lipid model systems. Food Chem, 2000, 69 (2), $167-$ 174. 
Table 1. Chemical composition of the essential oil of T. fontanesii from Algeria (mean of triplicates)

\begin{tabular}{|c|c|c|c|c|c|c|c|}
\hline \multirow[t]{3}{*}{$\mathrm{N}^{\circ}$} & \multirow[t]{3}{*}{ Compounds } & \multirow[t]{3}{*}{$\mathbf{R I}^{\mathrm{a}}$} & \multirow[t]{3}{*}{$\mathbf{R I}^{\mathbf{b}}$} & \multicolumn{3}{|c|}{ Area \% } & \multirow{3}{*}{$\begin{array}{l}\mathbf{H D} \\
\mathbf{T}_{\mathrm{TIZ}}\end{array}$} \\
\hline & & & & \multicolumn{3}{|c|}{ EMI } & \\
\hline & & & & $\mathbf{T}_{\mathbf{M}}$ & $\mathbf{T}_{\text {OEC }}$ & $\mathbf{T}_{\mathrm{TIZ}}$ & \\
\hline 1 & $\alpha$-Thujene & 930 & 924 & $0.9 \pm 0.07$ & $2.2 \pm 0.05$ & $0.8 \pm 0.1$ & $1.2 \pm 0.08$ \\
\hline 2 & $\alpha$-Pinene & 939 & 930 & $4.3 \pm 0.8$ & $2.9 \pm 0.04$ & $1.2 \pm 0.8$ & $3.2 \pm 1.01$ \\
\hline 3 & Camphene & 954 & 944 & $\operatorname{tr}$ & $\operatorname{tr}$ & $\operatorname{tr}$ & $0.2 \pm 0.01$ \\
\hline 4 & $\beta$-Pinene & 979 & 973 & $0.3 \pm 0.02$ & $0.3 \pm 0.03$ & $0.2 \pm 0.1$ & $0.1 \pm 0.01$ \\
\hline 5 & Myrcene & 991 & 989 & $1.7 \pm 0.08$ & $2.0 \pm 0.7$ & $1.6 \pm 0.4$ & $1.5 \pm 0.03$ \\
\hline 6 & $\alpha$-Phellandrene & 1003 & 1002 & $0.2 \pm 0.01$ & $0.3 \pm 0.01$ & $\operatorname{tr}$ & $0.2 \pm 0.02$ \\
\hline 7 & $\delta$-3 Carene & 1011 & 1008 & $\operatorname{tr}$ & $\operatorname{tr}$ & $\operatorname{tr}$ & $\operatorname{tr}$ \\
\hline 8 & $\alpha$-Terpinene & 1017 & 1014 & $1.8 \pm 0.03$ & $2.7 \pm 0.02$ & $1.8 \pm 0.7$ & $1.7 \pm 0.08$ \\
\hline 9 & $p$-Cymene & 1025 & 1023 & $14.3 \pm 1.3$ & $9.2 \pm 1.2$ & $10.5 \pm 0.2$ & $17.5 \pm 1.2$ \\
\hline 10 & Limonene & 1029 & 1027 & $\operatorname{tr}$ & $1.1 \pm 0.03$ & $\operatorname{tr}$ & $1.01 \pm 0.02$ \\
\hline 11 & $\gamma$-Terpinene & 1060 & 1059 & $11.6 \pm 1.5$ & $12.6 \pm 0.1$ & $14.9 \pm 0.8$ & $8.8 \pm 0.9$ \\
\hline 12 & Trans-Sabinene hydrate & 1070 & 1067 & - & $0.2 \pm 0.02$ & - & $0.3 \pm 0.01$ \\
\hline 13 & Linalool & 1097 & 1100 & $2.3 \pm 0.9$ & $3.8 \pm 0.8$ & $1.9 \pm 0.1$ & $3.7 \pm 0.01$ \\
\hline 14 & Borneol & 1166 & 1167 & $\operatorname{tr}$ & - & $\operatorname{tr}$ & $0.3 \pm 0.05$ \\
\hline 15 & Terpinen-4-ol & 1177 & 1178 & $0.3 \pm 0.01$ & $0.3 \pm 0.07$ & $0.2 \pm 0.1$ & $0.2 \pm 0.01$ \\
\hline 16 & Carvacrol methyl ether & 1245 & 1244 & $0.5 \pm 0.02$ & $1.4 \pm 0.09$ & $0.3 \pm 0.1$ & $0.4 \pm 0.02$ \\
\hline 17 & Thymol & 1290 & 1295 & $0.6 \pm 0.1$ & $1.5 \pm 0.3$ & $1.3 \pm 0.3$ & $0.3 \pm 0.08$ \\
\hline 18 & Carvacrol & 1299 & 1311 & $59.8 \pm 1.3$ & $55.1 \pm 0.8$ & $63.9 \pm 1.9$ & $54.7 \pm 1.2$ \\
\hline 19 & $\alpha$-Gurjunene & 1411 & 1412 & $0.3 \pm 0.05$ & $0.3 \pm 0.01$ & $0.3 \pm 0.1$ & $0.2 \pm 0.01$ \\
\hline 20 & $\beta$-Caryophyllene & 1419 & 1422 & $0.4 \pm 0.08$ & $0.6 \pm 0.02$ & $0.4 \pm 0.1$ & $0.4 \pm 0.01$ \\
\hline 21 & Aromadendrene & 1447 & 1442 & $0.1 \pm 0.01$ & - & $0.1 \pm 0.06$ & $0.2 \pm 0.02$ \\
\hline 22 & allo-Aromadendrene & 1460 & 1464 & $0.2 \pm 0.03$ & $\operatorname{tr}$ & $\operatorname{tr}$ & $\operatorname{tr}$ \\
\hline 23 & Bicyclogermacene & 1472 & 1499 & - & - & $0.2 \pm 0.1$ & - \\
\hline 24 & $\gamma$-Cadinene & 1514 & 1515 & $\operatorname{tr}$ & $\operatorname{tr}$ & $0.1 \pm 0.09$ & - \\
\hline 25 & $\delta$-Cadinene & 1523 & 1526 & $0.1 \pm 0.01$ & $\operatorname{tr}$ & $0.1 \pm 0.02$ & - \\
\hline 26 & Spathulenol & 1587 & 1583 & $0.2 \pm 0.01$ & $0.1 \pm 0.01$ & $\operatorname{tr}$ & $0.3 \pm 0.06$ \\
\hline 27 & Caryophylleneoxide & 1583 & 1589 & $\operatorname{tr}$ & $\operatorname{tr}$ & $\operatorname{tr}$ & $1.1 \quad 0.03$ \\
\hline \multicolumn{2}{|c|}{ Monoterpenes (\%) : } & & & 35.1 & 33.5 & 31 & 35.71 \\
\hline \multicolumn{2}{|c|}{ Oxygenated monoterpenes (\%) : } & & & 63.5 & 62.1 & 67.6 & 59.6 \\
\hline \multicolumn{2}{|c|}{ Sesquiterpenes (\%): } & & & 1.1 & 0.9 & 1.2 & 0.8 \\
\hline \multicolumn{2}{|c|}{ Oxygenated sesquiterpenes (\%) } & & & 0.2 & 0.1 & $\operatorname{tr}$ & 0.4 \\
\hline \multicolumn{2}{|c|}{ Identified compounds (\%) : } & & & 99.9 & 96.9 & 99.8 & 95.6 \\
\hline
\end{tabular}

$\operatorname{tr}: \operatorname{traces}(<0.1 \%)$ 
$\mathrm{RI}^{\mathrm{a}}$ :Retention indices (Adams)

$\mathrm{RI}^{\mathrm{b}}$ : Retention indices relative to $\mathrm{C}_{7}-\mathrm{C}_{30}$ on the HP-5MS capillary column

Table 2. $\mathrm{IC}_{50}$ values $(\mu \mathrm{g} / \mathrm{mL})$ of $T$. fontanesii essential oil and BHT

\begin{tabular}{|c|c|c|c|c|}
\hline Assays & $\mathrm{T}_{\mathrm{M}}$ & $\mathrm{T}_{\mathrm{TIZ}}$ & $\mathrm{T}_{\mathrm{OEC}}$ & BHT \\
\hline DPPH & $83.8 \pm 0.5$ & $57.3 \pm 1.35$ & $91.2 \pm 1.1$ & $18.3 \pm 0.8$ \\
\hline Reducing power & $103.9 \pm 0.4$ & $63.8 \pm 0.17$ & $112.6 \pm 1.8$ & $9.7 \pm 1.23$ \\
\hline$\beta$-carotene & $167.2 \pm 0.9$ & $148.9 \pm 0.45$ & $236.7 \pm 1.4$ & $67.8 \pm 0.1$ \\
\hline
\end{tabular}

$\mathbf{T}_{\mathbf{M}}:$ T. fontanesii from Miliana; $\mathbf{T}_{\mathbf{T I Z}}:$ T. fontanesii from Tarik Ibn Ziad; $\mathbf{T}_{\mathbf{O E C}}:$ T. fontanesii from Oued El Chorfa 